\title{
Biodegradation of the pyrethroid pesticide cyfluthrin by the halophilic bacterium Photobacterium ganghwense isolated from coral reef ecosystem
}

\author{
V. S. JAYASREE*, K. S. SOBHANA, PRIYANKA POULOSE*, KEERTHI R. BABU*, S. JASMINE, \\ L. RANJTH, R. SARAVANAN, H. JOSE KINGSLY, K. R. SREENATH, K. K. JOSHI, RANI MARY \\ GEORGE AND A. GOPALAKRISHNAN \\ ICAR-Central Marine Fisheries Research Institute, P. B. No. 1603, Ernakulam North P. O., Kochi - 682 018, Kerala, India \\ ${ }^{*}$ Cochin University of Science and Technology, Cochin University P. O., Kochi - 682 022, Kerala, India \\ e-mail: sobhanapradeep11@gmail.com
}

\begin{abstract}
A halophilic bacterial strain T14 isolated from the mucus of coral Acropora formosa was found to be highly effective in degrading the pyrethroid pesticide, cyfluthrin. T14 was identified as Photobacterium ganghwense (GenBank Accession No. MT360254) based on phenotypic and biochemical characteristics as well as by 16S rRNA gene sequence analysis. The pyrethroid degrading efficiency of $P$. ganghwense T14 strain was examined under different culture conditions. It was observed that $P$. ganghwense T14 was able to utilise cyfluthrin as a sole carbon source and was found to grow on mineral medium with pesticide concentrations ranging from 10 to $100 \mathrm{mg} \mathrm{l}^{-1}$. Optimal temperature and $\mathrm{pH}$ conditions for efficient cyfluthrin degradation by $P$. ganghwense T14 were determined as $30^{\circ} \mathrm{C}$ and 8 respectively. Degradation of cyfluthrin by $P$. ganghwense T14 was quantitated by gas chromatography-tandem mass spectrometry (GC-MS/MS). Mineral medium supplemented with $100 \mathrm{mg} \mathrm{l}^{-1}$ cyfluthrin and inoculated with $P$. ganghwense T14 $\left(10^{6}\right.$ cells ml-1) recorded $92.13 \%$ pesticide decomposition within $120 \mathrm{~h}$. Cytotoxicity assay on a fish cell line EM4SpEx derived from the grouper Epinephelus malabaricus, revealed a drastic reduction in cyfluthrin toxicity as evidenced by reduction in the intensity of cell destruction as well as morphological changes when exposed to $P$. ganghwense T14 treated filtrate, in comparison with that of parent cyfluthrin filtrate. Results of the study clearly indicated potential bioremediative use of $P$. ganghwense T14 in cyfluthrin contaminated sites.
\end{abstract}

Keywords: Biodegradation, Cyfluthrin, Cytotoxicity, Halophilic bacterium, Pesticide degradation, Photobacterium ganghwense, Pyrethroid

\section{Introduction}

Tropical marine ecosystems including coral reefs, seagrass meadows and mangrove forests are of major concern when considering the threatening impact of chemical contaminants (Ferguson and Johannes, 1975). Growing urban affluence caused human populations to expand adjacent to these ecosystems causing profound environmental hazards including worsening of water quality and problems of waste disposal (Connell and Hawker, 1991). Both tropical and temperate marine ecosystems share common sources of chemical pollutants primarily the terrestrial runoff from rivers, agricultural, industrial and domestic activities (Esther et al., 1997). Near shore coastal areas are severely susceptible to these runoffs, especially during the monsoon season (Lewis et al., 2009). Considering the inevitable role of chemical pesticides in agricultural fields and to minimise the hazardous after-effects, use of organochloride pesticides were controlled in the beginning of 2000 leading to a significant increase in the use of pyrethroid pesticides.
Owing to the comparatively faster degradation of organic insecticide pyrethrins, their chemical analogs called pyrethroids were synthesised. Nowadays, pyrethroids contribute more than $25 \%$ of the world's total pesticide market (Chen et al., 2011). Thus the run offs started showing more of the presence of pyrethroids than organochlorides.

Pesticide pollution in aquatic ecosystems attract increasing attention owing to bioaccumulation of pesticides in aquatic organisms, which would lead to food safety and human health issues. Further, the impact of chemical stressors on mangrove forests, seagrass meadows and coral reefs are being studied and discussed seriously in the context of ecosystem management and ecological risk assessment. Among the variety of pollutants assessed in tropical marine ecosystems; heavy metals, petroleum and pesticides received significant attention. Pesticides from agricultural and land runoff can affect coral reproduction, growth and other physiological processes including recruitment of a variety of organisms (Esther et al., 1997). 
Herbicides, in particular, can destructively interfere with the symbiotic algae resulting in coral bleaching. Until late 1960's, islands and coastal waters of the tropics and subtropics were considered as highly productive, unique and speciose ecosystems. But in early 1970's, as the exploitation of natural resources started extending more towards the tropic regions from the temperates, these economically and culturally valuable pristine ecosystems started declining especially the shallow water tropical marine regions (Johannes and Betzer, 1975). Once pesticides or other chemical pollutants reach the coral vicinity, the response towards the pollutant varies with the coral morphology. For example, pesticide susceptibility of branching species of corals would be more than the massive corals (Stebbing and Brown, 1984). Similarly, large polyped species are more resistant to heavy metal exposure than small polyped species (Scott, 1990). Difference in the orientation, growth form and mucus production of the coral species also have influence on their ability to withstand sediment particles falling on their surfaces (Wijsman, 1974). The lipid layer that covers the coral skeleton can facilitate the direct uptake of lipophilic chemicals like pesticides thereby making the coral colonies more susceptible to contaminants dissolved in seawater or adsorbed on particles.

Published literature suggests occasional presence of pesticides in coral reefs, sometimes in high concentrations. For instance, in a baseline study conducted on the presence of organochloride pesticides in the Great Barrier Reef, an alarming presence of lindane was consistently detected with concentrations of 0.05 to $0.39 \mathrm{ng} \mathrm{g}^{-1}$ wet weight in coral reef organisms (Olfson, 1978). Shockingly, coral tissues collected off Florida had the presence of DDT (Dichloro-diphenyl-trichloro-ethane) at 3 to $12 \mathrm{ng} \mathrm{g}^{-1}$ wet weight and dieldrin at 0.260 to $0.320 \mathrm{ng} \mathrm{g}^{-1}$ wet weight (McCloskey and Chesher, 1971). A frightening observation was that, $100 \%$ of the gorgonian corals and $96.6 \%$ of the scleractinian corals sampled off the northern Florida Keys showed presence of pesticides at concentrations upto $7.6 \mathrm{mg} \mathrm{g}^{-1}$ wet weight (Glynn et al., 1989) with chlordane being the most frequently encountered pesticide. Glynn (1995) conducted a study on sediment and biota samples from Pennekamp Coral Reef State Park and Key Largo National Marine Sanctuary, Florida, USA and their results revealed presence of organochloride pesticides in sediments and tissues of sponges, corals, crustaceans and fishes.

Coral reefs harbour a wide array of microorganisms and persistent influx of chemical stressors would cause ecological disturbance on these microbial communities leading to development of resistant strains. Pesticides reaching the coral reefs can have either beneficial or detrimental effect on the associated microflora.
Beneficial communities would utilise pesticides as a source of nutrients facilitating their growth and survival whereas sensitive ones might get decimated (DeLorenzo et al., 2001). During the course of our study on marine bacterial diversity associated with coral reefs, we isolated two strains (T14 and T25) of the halophilic bacterium, Photobacterium ganghwense from mucus of the scleractinian coral Acropora spp. Wang et al. (2019) reported pyrethroid degradation potential of P. ganghwense strain 6046 (PGS6046) isolated from an offshore seawater environment of Ningbo, China and therefore we attempted to probe in to the pyrethroid degradation potential of the two bacterial strains T14 and T25 using cyfluthrin.

Cyfluthrin $\left(\mathrm{C}_{22} \mathrm{H}_{18} \mathrm{Cl}_{2} \mathrm{FNO}_{3}\right)$ is a broad spectrum synthetic ester pyrethroid commonly recommended against Lepidopteran pests affecting solanaceous crops. Light sensitivity of first generation pyrethroids necessitated a second generation which overcame most of its shortcomings and became a suitable candidate for agricultural, veterinary, greenhouse and other public facilities (Laskowski, 2002). Pyrethroids are the most common active ingredient in commercially available insect sprays and are the domain pesticide for malaria control. Widespread and long-term use of cyfluthrin has led to substantial pesticide residue levels in aquatic ecosystems as well as aquatic products affecting both human and aquatic health (Almakkawy and Madbouly, 1999). Based on their toxicological and physical properties, pyrethroids are categorised into two separate classes viz., Type I and Type II. Type I pyrethroids do not have a cyano group and Type II pyrethroids have a cyano group in their structure (Laskowski, 2002). Difficulty in degradation along with its critical environmental impacts has heightened the necessity of an efficient bioremediative strategy for cyfluthrin contaminated sites. The present study investigated the ability of Photobacterium ganghwense isolated from coral reef ecosystem to biodegrade cyfluthrin pesticide.

\section{Materials and methods}

\section{Chemicals and microbiological media}

All chemicals used in the study were of analytical grade and procured form Hi Media India Pvt. Ltd., Mumbai, India. The microbiological media used were procured from BD-Difco, USA. Difco Nutrient agar and Nurient broth were supplemented with $2.2 \% \mathrm{NaCl}$ to get a final concentration of 3\%. Mineral Medium (MM) containing $\left(\mathrm{NH}_{4}\right)_{2} \mathrm{SO}_{4}-2 \mathrm{~g} \mathrm{l}^{-1} ; \mathrm{MgSO}_{4}-0.2 \mathrm{~g} \mathrm{l}^{-1} ; \mathrm{CaCl}_{2}$ $0.01 \mathrm{~g} \mathrm{l}^{-1} ; \mathrm{FeSO}_{4}-0.005 \mathrm{~g} \mathrm{l}^{-1} ; \mathrm{MnCl}_{2}-0.002 \mathrm{~g} \mathrm{l}^{-1} ; \mathrm{K}_{2} \mathrm{HPO}_{4}$ - $10.5 \mathrm{~g} \mathrm{l}^{-1}$ and $\mathrm{KH}_{2} \mathrm{PO}_{4}-4.5 \mathrm{~g} \mathrm{l}^{-1}$ was prepared in seawater. The pyrethroid pesticide cyfluthrin (Solfac WP 10) having $10 \%$ active ingredient was procured from Bayer (India) Ltd., Hyderabad, India. 


\section{Sample collection and isolation of bacterial strains}

Two bacterial strains designated as T14 and T25 were isolated from coral mucus of Acropora formosa and Acropora hyacinthus respectively from the coral reef ecosystem in Thoothukudi $\left(8^{\circ} 59.279\right.$ ' $\mathrm{N}$ and $078^{\circ}$ 15.008 'E). Predominant colonies observed growing on Difco Nutrient Agar (NA) medium, having light cream, opaque, round and bulged appearance were subjected to further investigations. Well isolated single colonies were re-streaked several times on NA plates so as to obtain pure colonies. The isolated strains were routinely cultivated aerobically at $28 \pm 2{ }^{\circ} \mathrm{C}$ in Difco Nutrient Agar medium and were preserved in double strength Nutrient Broth with $50 \%$ glycerol at $-80^{\circ} \mathrm{C}$ and also in semisolid agar at room temperature using mineral oil overlay method (Hartsell, 1953).

\section{Phenotypic and biochemical characterisation}

The isolated bacterial colonies were identified on the basis of their morphological, physiological and biochemical characteristics following Baumann and Baumann (1984). Unless otherwise stated, all of the biochemical and physiological tests used Difco Nutrient Agar as the basal medium and for all the tests performed, incubation was carried out at $28 \pm 2^{\circ} \mathrm{C}$ for $48 \mathrm{~h}$.

\section{Molecular and phylogenetic analysis}

\section{DNA extraction, PCR $16 S$ rDNA amplification and sequencing}

Bacterial genomic DNA was extracted using standard phenol chloroform extraction method (Sambrook and Russell, 2006). 16S rRNA gene was amplified with the universal primer pair $27 \mathrm{~F}$ (5' AgAGTtTGATCCTGG CTCAG 3') and 1492R (5' TACGGCTACCTTGTTACGACT T 3'). The reaction mixture had 10 pmol of each primer, 50-100 ng of DNA template and $12.5 \mu \mathrm{l}$ of $2 x$ Dream Taq Green PCR Master Mix (Thermo Fischer). DNA was amplified by PCR cycling profile comprising an initial denaturation at $94^{\circ} \mathrm{C}$ for $5 \mathrm{~min}$ followed by 35 cycles of denaturation at $94^{\circ} \mathrm{C}$ for $60 \mathrm{~s}$, annealing at $58^{\circ} \mathrm{C}$ for $60 \mathrm{~s}$, elongation at $72^{\circ} \mathrm{C}$ for $75 \mathrm{~s}$ and a final extension at $72^{\circ} \mathrm{C}$ for 10 min (Karlsen et al., 2014) in a Thermal cycler (Applied Biosystems, USA). The PCR products were subjected to agarose gel electrophoresis, stained with ethidium bromide (EtBr) and visualised in a gel documentation system (Azure Biosystems, USA). The amplified products were sequenced in both forward and reverse directions with the same set of primers in Applied Biosystems AB 3730 capillary sequencer at the sequencing facility. The raw DNA sequences were edited using BioEdit sequence alignment editor version 7.0.5.2 (Hall, 1999). Sequence analysis for homology comparison used the European Nucleotide Archive, ENA (https://www.ebi.ac.uk/ena); Ribosomal Database Project, RDP (https://rdp.cme. msu.edu); EzBioCloud16S database (www.ezbiocloud. net) and National Centre for Biotechnology Information GenBank Database (using the Basic Local Alignment Search Tool, BLAST). For species level identification, only similarity score $\geq 99 \%$ with the reference sequence of a classified species was considered. A phylogenetic tree was constructed by neighbour-joining method using MEGA X software (Tamura, 2011). Distance matrices were calculated using Kimura's 2-parameter correction followed by performing bootstrap analysis (1000 replicates) to check the robustness of groupings.

\section{Optimisation of cyfluthrin degradation test}

In order to assess the cyfluthrin degrading potential of the bacterial strains T14 and T25, both strains were allowed to grow in a medium containing cyfluthrin. Cyfluthrin stock (100 $\mathrm{mg} \mathrm{l}^{-1}$ ) was prepared by emulsifying in sterile distilled water at $20^{\circ} \mathrm{C}$ for maximum solubility (Tomlin, 1997) using a sterile disposable syringe holding a 21 guage needle. Bacterial cells at $10^{6}$ cells $\mathrm{ml}^{-1}$ were inoculated in $50 \mathrm{ml}$ of mineral medium (MM) $(\mathrm{pH}-7.0)$ supplemented with cyfluthrin at concentrations of 0,10 , 20,50 and $100 \mathrm{mg} \mathrm{l}^{-1}$ (each dose in triplicates) which were incubated at $28^{\circ} \mathrm{C}(\mathrm{pH} 7)$ on a rotary shaker at $180 \mathrm{rpm}$ for $120 \mathrm{~h}$ ( 5 days) and the bacterial cell density was monitored by measuring $\mathrm{OD}$ at $600 \mathrm{~nm}\left(\mathrm{OD}_{600}\right)$ at every $24 \mathrm{~h}$ interval (Grant et al., 2002) in a spectrophotometer (Nanodrop 1C; Thermo Scientific, USA).

The strain T14 showing highest biomass increase in the presence of cyfluthrin was selected and growth conditions (temperature and $\mathrm{pH}$ ) were optimised for this strain to facilitate further analyses. For optimisation of temperature, cells of the selected strain T14 $\left(10^{6}\right.$ cells m l-1) was inoculated in $\mathrm{MM}$ ( $\mathrm{pH}$ 7) supplemented with $100 \mathrm{mg} \mathrm{l}^{-1}$ cyfluthrin (which showed highest growth of T14 strain among the 4 different concentrations tested) and incubated at different temperatures $\left(25,30,37\right.$ and $\left.45^{\circ} \mathrm{C}\right)$ at $\mathrm{pH} 7$ and the cell density was monitored by measuring $\mathrm{OD}_{600}$ at $24 \mathrm{~h}$ interval up to $120 \mathrm{~h}$. Subsequently, optimal $\mathrm{pH}$ for growth was assessed by monitoring bacterial cell density in $\mathrm{MM}$ at varying $\mathrm{pH}$ levels $(6,7,8$ and 9), supplemented with $100 \mathrm{mg} \mathrm{l}^{-1}$ cyfluthrin and incubated at $30^{\circ} \mathrm{C}$ (which recorded the highest growth of T14 strain, among the 4 different temperatures tested). Growth was monitored by measuring $\mathrm{OD}_{600}$ at $24 \mathrm{~h}$ interval up to $120 \mathrm{~h}$. 
Evaluation and quantification of in vitro cyfluthrin degradation by $P$. ganghwense T14

Efficacy of cyfluthrin degradation by T14 strain was evaluated by inoculating $10^{6}$ cells ml-1 in $50 \mathrm{ml} \mathrm{MM}$ at optimised $\mathrm{pH}(8)$, supplemented with $100 \mathrm{mg} \mathrm{l}^{-1}$ cyfluthrin and incubated for $120 \mathrm{~h}$ at the optimised temperature of $30^{\circ} \mathrm{C}$ (Test T). Degradation test was performed in amber bottles and incubated in dark condition in order to extend the half life of cyfluthrin. MM inoculated with bacterial strain T14 $\left(10^{6}\right.$ cells ml $\left.^{-1}\right)$ without cyfluthrin (Control C1) and uninoculated $\mathrm{MM}$ supplemented with $100 \mathrm{mg} \mathrm{l}^{-1}$ cyfluthrin (Control C2) were maintained as controls and incubated under similar conditions. At every $24 \mathrm{~h}$ of incubation, cell density was monitored by measuring $\mathrm{OD}_{600}$. At the end of $120 \mathrm{~h}$ of incubation period, the samples were centrifuged at $2500 \mathrm{~g}$ for $10 \mathrm{~min}$ and the supernatants were collected and filtered sequentially in $0.45 \mu \mathrm{m}$ and $0.22 \mu \mathrm{m}$ filters using sterile membrane filtration units (Millipore, USA), so as to ensure complete removal of bacterial cells. The filtrates were stored in amber bottles under refrigerated conditions until further analyses. The treated filtrate from test $\mathrm{T}$ along with the control filtrate $\mathrm{C} 2$ were analysed by gas chromatographytandem mass spectrometry (GC-MS/MS) to quantify cyfluthrin content post-treatment, in order to ascertain cyfluthrin degradation efficacy of P.ganghwense T14. The filtrates from $\mathrm{T}, \mathrm{C} 1$ and $\mathrm{C} 2$ were also tested on a fish cell line to evaluate comparative cytotoxicity, in order to test if there is any reduction in cyfluthrin cytotoxicity owing to T14 treatment.

GC-MS/MS analysis

Analysis was performed as per EN 15662:2009 QuEChERS (Quick, Easy, Cheap, Effective, Rugged and Safe) method (Anastassiades et al., 2003; AOAC 2007; AFNOR, 2009) which is based on liquid-liquid partitioning with acetonitrile followed by a cleanup step with dispersive-SPE (Solid Phase Extraction). Ten microlitre of acetonitrile cooled at $-18^{\circ} \mathrm{C}$ was added to $10 \mathrm{ml}$ of sample (filtrate), vortexed for $1 \mathrm{~min}$ and then $4 \mathrm{~g}$ of $\mathrm{MgSO}_{4}, 1 \mathrm{~g}$ of $\mathrm{NaCl}, 1 \mathrm{~g}$ of $\mathrm{C}_{6} \mathrm{H}_{3} \mathrm{Na}_{3} \mathrm{O}_{7} \cdot 2 \mathrm{H}_{2} \mathrm{O}$ and $1 \mathrm{~g}$ of $\mathrm{C}_{6} \mathrm{H}_{6} \mathrm{Na}_{2} \mathrm{O}_{7} 0.1 \cdot 5 \mathrm{H}_{2} \mathrm{O}$ were added followed by manual shake for $1 \mathrm{~min}$ and centrifugation at $3500 \mathrm{rpm}$ for $8 \mathrm{~min}$. After this, a LTP step was applied to precipitate interferences where $3 \mathrm{ml}$ of the supernatant was transferred to a $15 \mathrm{ml}$ tube and placed in freezer $\left(-18^{\circ} \mathrm{C}\right)$ for $3 \mathrm{~h}$. For d-SPE clean-up step, $2 \mathrm{ml}$ of the resultant supernatant was transferred to another $15 \mathrm{ml}$ tube containing $300 \mathrm{mg}$ of $\mathrm{MgSO}_{4}, 100 \mathrm{mg}$ of primary secondary amine (PSA), $100 \mathrm{mg}$ of graphitised carbon black (GCB) and $100 \mathrm{mg}$ of $\mathrm{C} 18$. The tube was vortexed $(1 \mathrm{~min})$ and centrifuged at
$3500 \mathrm{rpm}$ for $8 \mathrm{~min}$. Gas chromatography analysis coupled to tandem mass spectrometry (GC-MS/MS) was used for determination in an Agilent 7000 S GCMS TRIPLE QUAD GC SYSTEM 7890. Internal standard (Heptachlor epoxide B) was added at a concentration of $1 \mu \mathrm{g} \mathrm{ml}^{-1}$ in both extracts, prior to injection. Detector used was Q Trap MS/MS system. The chromatograms were recorded and analysed. Cyfluthrin degradation rate was calculated using the formula:

$$
\text { Degradation rate }(\%)=\left[\left(\mathrm{C}_{\mathrm{C} 2}-\mathrm{C}_{\mathrm{T}}\right) / \mathrm{C}_{\mathrm{C} 2}\right] \times 100
$$

where, $\mathrm{C}_{\mathrm{C} 2}$ and $\mathrm{C}_{\mathrm{T}}$ represent cyfluthrin concentration in $\mathrm{C} 2$ and $\mathrm{T}$ filtrates, respectively.

Comparative cytotoxicity evaluation of $T, C 1$ and $C 2$ filtrates using fish cell line EM4SpEx

EM4SpEx cell line derived from Epinephelus malabaricus developed at ICAR-Central Marine Fisheries Research Institute (ICAR-CMFRI), Kochi was used for cytotoxicity evaluation of the filtrates. Initially, to check cyfluthrin induced cytotoxicity on EM4SpEx cell line, cell monolayers (at $90 \%$ confluency) were treated with different concentrations of the pesticide cyfluthrin $(0.25$, 0.5 and $1 \mu \mathrm{g} \mathrm{m} \mathrm{l}^{-1}$ of the active ingredient) prepared in Leibovitz L-15 [containing $2 \%$ foetal bovine serum (FBS) and $20 \mathrm{~mm}$ HEPES buffer] in 6-well tissue culture plates (in triplicates) along with control cells without exposure to pesticide treatment and incubated at $28^{\circ} \mathrm{C}$ in dark for $72 \mathrm{~h}$ (3 days) in a refrigerated incubator (Barnstead-Labline, USA). Cells were monitored under phase contrast objective of an inverted microscope (Nikon TS100). Evidence of cytotoxicity in the form of cell destruction was observed in all the treatments in a dose-dependent manner to cyfluthrin exposure and complete cell destruction was observed in $72 \mathrm{~h}$. Control cells remained intact without any cell damage. Subsequently, filtrates from T, C1 and $\mathrm{C} 2$ were used for evaluating comparative cytotoxicity on EM4SpEx cell line. EM4SpEx cell monolayers (at 90\% confluency) were treated with $500 \mu \mathrm{l}$ of filtrate from T, $\mathrm{C} 1$ (no cyfluthrin) and $\mathrm{C} 2$ in L-15 medium (supplemented with 2\% FBS and $20 \mathrm{~mm}$ HEPES) along with control cells (C0) without addition of filtrate (inoculated with $500 \mu$ l of sterile $\mathrm{MM}$ alone) and incubated at $28^{\circ} \mathrm{C}$ in dark for $72 \mathrm{~h}$ in a refrigerated incubator. All the treatments were done in triplicate wells in 6 well plates. Changes in morphology of the cells were monitored under inverted microscope under phase contrast objective. Photomicrographs were taken after $72 \mathrm{~h}$ of incubation and cell morphologies were compared. 


\section{Statistical analysis}

Statistical analysis of the data was performed using one-way analysis of variance employing SPSS software ver. 20.0 (SPSS Inc., Chicago, Illinois, USA) and $\mathrm{p}<0.05$ was considered statistically significant.

\section{Results and discussion}

\section{Isolation and identification of bacterial strains}

\section{Phenotypic and biochemical characteristics}

Both the bacterial strains isolated viz., T14 and T25 showed growth in nutrient agar and formed slightly cream coloured circular (3 $\mathrm{mm}$ dia) smooth convex shiny and opaque colonies of entire margin, when incubated for $48 \mathrm{~h}$ at $30^{\circ} \mathrm{C}$ (Fig. 1a, b). Both strains are motile, aerobic Gram negative rods which grows only at $\mathrm{NaCl}$ concentration ranging from 1 to $7 \%$ with optimum being $6 \%$. Based on phenotypic and biochemical characteristics, both T14 and T25 strains were identified as Photobacterium ganghwense (Table 1). Characteristics of the type strain P. ganghwense FR $1311^{\mathrm{T}}$ were used for taxonomic comparison.

The type strain $P$. ganghwense sp. nov. FR $1311^{\mathrm{T}}$ reported by Park et al. (2006), had optimum temperature and $\mathrm{pH}$ as $35^{\circ} \mathrm{C}$ and $8-9$ respectively. Also it did not grow below $10{ }^{\circ} \mathrm{C}$ and above $45^{\circ} \mathrm{C}$ and had a $\mathrm{pH}$ range between 5-11. But for T14 and T25 strains, optimum growth was observed at a comparatively lower temperature of $30^{\circ} \mathrm{C}$; however, $\mathrm{pH}$ tolerence was similar to the type strain i.e., between 5-11 with optimum at 8, above $\mathrm{pH} 11$ no growth was observed. Both strains T14 and T25 exhibited significant morphological, physiological and biochemical similarities among themselves and with the type strain. Difference in the temperature optimum can be attributed to the variability of sources. Agler et al. (2016) reported on the genetical and physiological acclimatisation of microbiota in response to various biotic and abiotic factors.

\section{Molecular characterisation and phylogenetic analysis}

Based on 16S rRNA gene sequence analysis and homology search using BLAST in the NCBI GenBank database as well as with the EZ Biocloud, ENA and RDP nucleotide sequence databases, the strains T14 and T25 were identified as $P$. ganghwense. The genus Photobacterium was first described by Beijerinck in 1889. Based on phylogenetic analysis, Photobacterium genus showed close relation to the genus Vibrio (Anzai et al., 2000). P. ganghwense sp. nov. (designated as strain FR1311 ${ }^{\mathrm{T}}$ ) was first described by Park et al. (2006) as a halophilic bacterium isolated from seawater samples from Ganghwa Island, South Korea. Our strains T14 and T25 have similarity scores of 99.79 and $99.58 \%$ respectively, with the type strain $P$. ganghwense FR1311 ${ }^{\mathrm{T}}$. Sequences of both the strains T14 and T25 were deposited in NCBI GenBank with Accession Nos. MT360254 and MT360255 respectively. Fig. 2 depicts the phylogenetic tree constructed by neighbourjoining method using MEGA X software.

\section{Optimisation of conditions for cyfluthrin degradation}

Of the two strains of $P$. ganghwense tested, T14 was found to have better efficiency in cyfluthrin utilisation for growth which was noticeable from a dose dependent increase in cell density of T14 at all the four concentrations

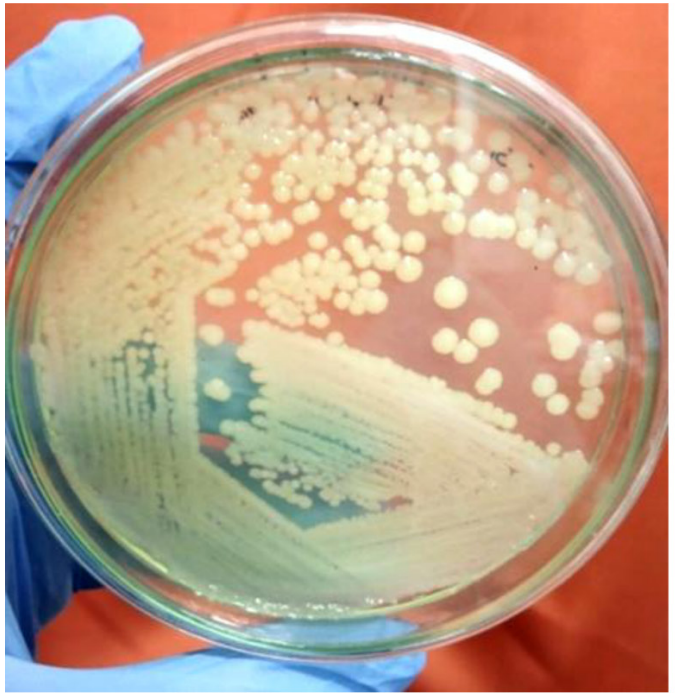

(a)

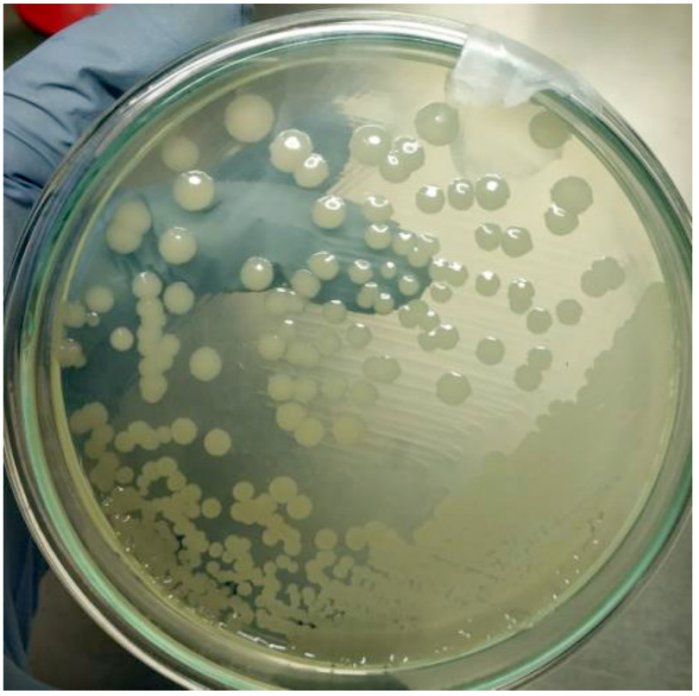

(b)

Fig. 1. Colony morphology of the bacterial strains (a) T14 and (b) T25 on Nutrient Agar plates 
Table 1. Phenotypic and biochemical characteristics of P. ganghwense strains T14 and T25 in comparison with Type strain P. ganghwense FR $1311^{\mathrm{T}}$

\begin{tabular}{|c|c|c|c|}
\hline Phenotypic and biochemical tests & $\begin{array}{l}\text { P. ganghwense T14 } \\
\text { (GenBank Acc. No. MT360254) }\end{array}$ & $\begin{array}{l}\text { P. ganghwense T25 } \\
\text { (GenBank Acc. No. MT360255) }\end{array}$ & $\begin{array}{l}\text { Type strain } \\
\left(P . \text { ganghwense } \mathrm{FR} 1311^{\mathrm{T}}\right)\end{array}$ \\
\hline Gram reaction & $-\mathrm{ve}$ & -ve & -ve \\
\hline Cell morphology & Rod & Rod & Rod \\
\hline Swarming on solid media & -ve & -ve & -ve \\
\hline Growth on TCBS agar & +ve (Green colony) & +ve (Green colony) & +ve (Green colony) \\
\hline Motility & $+\mathrm{ve}$ & $+\mathrm{ve}$ & $+\mathrm{ve}$ \\
\hline $\mathrm{VP}^{*}$ & $-\mathrm{ve}$ & -ve & -ve \\
\hline $\mathrm{MR}^{* *}$ & $+\mathrm{ve}$ & $+\mathrm{ve}$ & $+\mathrm{ve}$ \\
\hline Indole & $+\mathrm{ve}$ & + ve & $+\mathrm{ve}$ \\
\hline ONPG & $+\mathrm{ve}$ & $+\mathrm{ve}$ & $+\mathrm{ve}$ \\
\hline Esculin hydrolysis & $-\mathrm{ve}$ & Slight + ve & $-\mathrm{ve}$ \\
\hline Sodium gluconate & -ve & -ve & -ve \\
\hline Glycerol & $-\mathrm{ve}$ & -ve & $-\mathrm{ve}$ \\
\hline Citrate utilisation & $+\mathrm{ve}$ & $+\mathrm{ve}$ & $+\mathrm{ve}$ \\
\hline Nitrate reduction & $+\mathrm{ve}$ & $+\mathrm{ve}$ & $+\mathrm{ve}$ \\
\hline \multicolumn{4}{|l|}{ Growth in $\% \mathrm{NaCl}$} \\
\hline 1 & $+\mathrm{ve}$ & $+\mathrm{ve}$ & $+\mathrm{ve}$ \\
\hline 3 & $+\mathrm{ve}$ & + ve & $+\mathrm{ve}$ \\
\hline 5 & $+\mathrm{ve}$ & $+\mathrm{ve}$ & $+\mathrm{ve}$ \\
\hline 7 & $+\mathrm{ve}$ & $+\mathrm{ve}$ & $+\mathrm{ve}$ \\
\hline 8 & $-\mathrm{ve}$ & $-\mathrm{ve}$ & $-\mathrm{ve}$ \\
\hline \multicolumn{4}{|l|}{ Growth at $\left({ }^{\circ} \mathrm{C}\right)$} \\
\hline 4 & -ve & $-v e$ & $-\mathrm{ve}$ \\
\hline 10 & $+\mathrm{ve}$ & $+\mathrm{ve}$ & $+\mathrm{ve}$ \\
\hline 30 & $+\mathrm{ve}$ & $+\mathrm{ve}$ & $+\mathrm{ve}$ \\
\hline 35 & $+\mathrm{ve}$ & $+\mathrm{ve}$ & $+\mathrm{ve}$ \\
\hline 45 & $+\mathrm{ve}$ & $+\mathrm{ve}$ & $+\mathrm{ve}$ \\
\hline 50 & -ve & -ve & $-\mathrm{ve}$ \\
\hline \multicolumn{4}{|l|}{ Growth at $\mathrm{pH}$} \\
\hline 4 & $-\mathrm{ve}$ & -ve & $-\mathrm{ve}$ \\
\hline 5 & $+\mathrm{ve}$ & $+\mathrm{ve}$ & $+\mathrm{ve}$ \\
\hline 7 & $+\mathrm{ve}$ & $+\mathrm{ve}$ & $+\mathrm{ve}$ \\
\hline 11 & + ve & + ve & + ve \\
\hline 12 & - ve & - ve & - ve \\
\hline \multicolumn{4}{|l|}{ Amino acid utilisation } \\
\hline Arginine & $+\mathrm{ve}$ & $+\mathrm{ve}$ & $+\mathrm{ve}$ \\
\hline Ornithine & $-\mathrm{ve}$ & $-\mathrm{ve}$ & $-\mathrm{ve}$ \\
\hline Lysine & -ve & -ve & -ve \\
\hline Phenylalanine deaminase & -ve & -ve & -ve \\
\hline Tryptophan deaminase & -ve & -ve & -ve \\
\hline \multicolumn{4}{|l|}{ Acid from sugar } \\
\hline Adonitol & -ve & -ve & -ve \\
\hline Arabinose & -ve & $-v e$ & -ve \\
\hline Arabitol & $\mathrm{Ve}$ & - ve & -ve \\
\hline Cellobiose & -ve & -ve & -ve \\
\hline D-Arabinose & -ve & -ve & -ve \\
\hline Dextrose & $+\mathrm{ve}$ & $+\mathrm{ve}$ & $+\mathrm{ve}$ \\
\hline Dulcitol & $-\mathrm{ve}$ & $-v e$ & $-\mathrm{ve}$ \\
\hline Erythritol & $-\mathrm{ve}$ & -ve & $-\mathrm{ve}$ \\
\hline Fructose & $+\mathrm{ve}$ & $+\mathrm{ve}$ & $+\mathrm{ve}$ \\
\hline Galactose & $+\mathrm{ve}$ & $+\mathrm{ve}$ & $+\mathrm{ve}$ \\
\hline Inositol & $+\mathrm{ve}$ & $+\mathrm{ve}$ & $+\mathrm{ve}$ \\
\hline Inulin & $-\mathrm{ve}$ & -ve & $-\mathrm{ve}$ \\
\hline
\end{tabular}

"Voges-Proskauer; "*Methyl Red 


\begin{tabular}{|c|c|c|c|}
\hline Phenotypic and biochemical tests & $\begin{array}{l}\text { P. ganghwense T14 } \\
\text { (GenBank Acc. No. MT360254) }\end{array}$ & $\begin{array}{l}\text { P. ganghwense T25 } \\
\text { (GenBank Acc. No. MT360255) }\end{array}$ & $\begin{array}{l}\text { Type strain } \\
\left(P . \text { ganghwense } \mathrm{FR} 1311^{\mathrm{T}}\right)\end{array}$ \\
\hline L-Arabinose & $-\mathrm{ve}$ & -ve & $-\mathrm{ve}$ \\
\hline Lactose & -ve & -ve & -ve \\
\hline Malonate & -ve & -ve & $-\mathrm{ve}$ \\
\hline Maltose & + ve & + ve & + ve \\
\hline Mannitol & + ve & $+\mathrm{ve}$ & + ve \\
\hline Mannose & weak +ve & + ve & weak +ve \\
\hline Melibiose & -ve & -ve & -ve \\
\hline Melzitose & -ve & -ve & $-\mathrm{ve}$ \\
\hline Raffinose & -ve & -ve & -ve \\
\hline Rhamnose & -ve & -ve & -ve \\
\hline Salicin & $-\mathrm{ve}$ & $-\mathrm{ve}$ & $-\mathrm{ve}$ \\
\hline Sorbitol & -ve & -ve & $-\mathrm{ve}$ \\
\hline Sorbose & $-\mathrm{ve}$ & $-\mathrm{ve}$ & -ve \\
\hline Sucrose & - ve & -ve & $-\mathrm{ve}$ \\
\hline Trehalose & + ve & + ve & + ve \\
\hline Xylitol & -ve & -ve & -ve \\
\hline Xylose & $-\mathrm{ve}$ & $-\mathrm{ve}$ & -ve \\
\hline$\alpha$-methyl-D-Glucoside & -ve & -ve & -ve \\
\hline$\alpha$ - methyl-D-Mannoside & $-\mathrm{ve}$ & -ve & -ve \\
\hline \multicolumn{4}{|l|}{ Enzyme production } \\
\hline Urease & $-\mathrm{ve}$ & -ve & $-\mathrm{ve}$ \\
\hline$\alpha$-Glucoronidase & -ve & -ve & -ve \\
\hline$\alpha$-Galactosidase & -ve & -ve & -ve \\
\hline$\beta$-Xylosidase & -ve & -ve & -ve \\
\hline Gelatinase & + ve & + ve & $+\mathrm{ve}$ \\
\hline Lipase & -ve & -ve & $-\mathrm{ve}$ \\
\hline
\end{tabular}

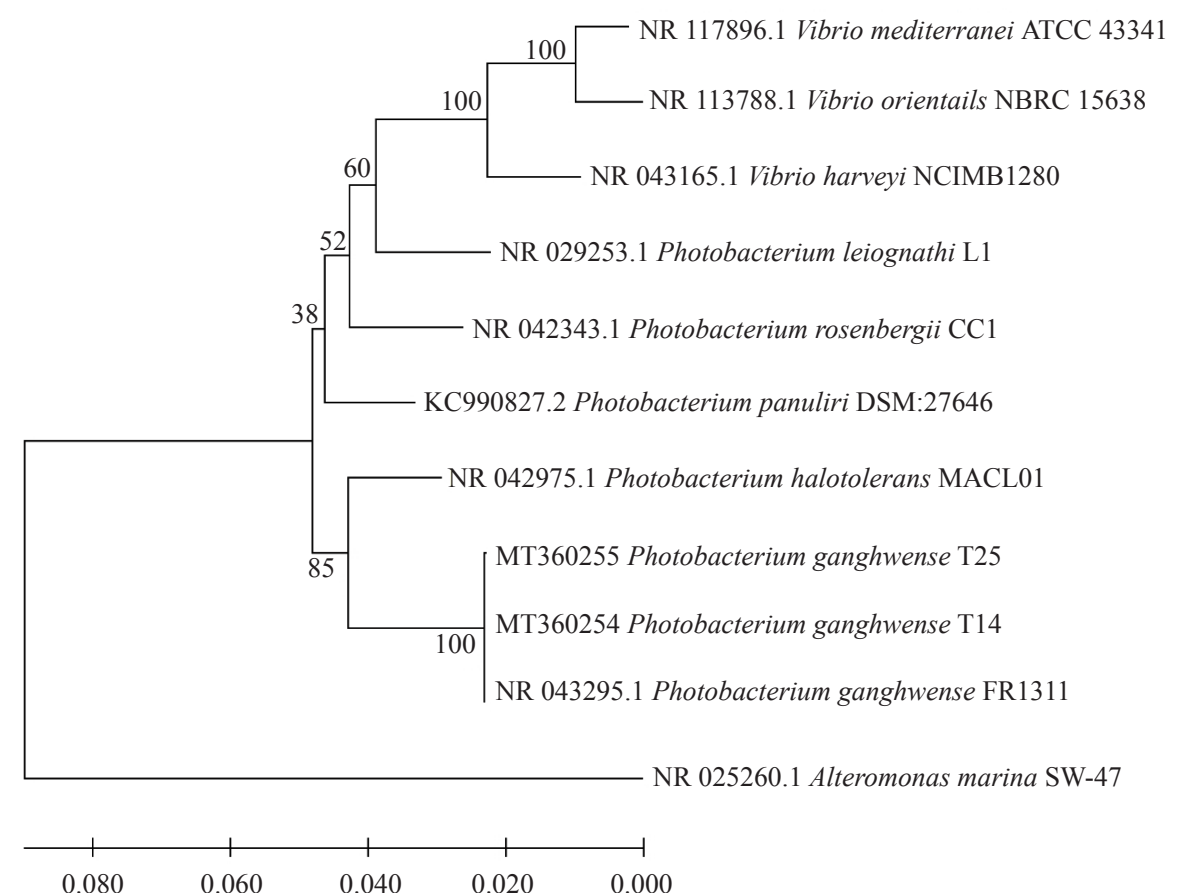

Fig. 2. Neighbor-joining phylogenetic tree based on 16S rRNA gene sequences of $P$. ganghwense T14 and T25 strains. Evolutionary distances were computed using Kimura's 2-parameter method with 1000 bootstrap replicates in MEGA X. Scale bar indicates mean number of substitutions per base. Bootstrap values are displayed at branch points 
$\left(10,20,50\right.$ and $\left.100 \mathrm{mg} \mathrm{l}^{-1}\right)$ of cyfluthrin tested. The cell biomass in all the treatments peaked at $48 \mathrm{~h}$ after which a reduction in growth was observed. The highest biomass for both the bacterial strains was recorded at $100 \mathrm{mg} \mathrm{l}^{-1}$ cyfluthrin concentration and the lowest for control samples without cyfluthrin $\left(0 \mathrm{mg} \mathrm{l}^{-1}\right)$ (Fig. 3). For the strain T25, increase in cell density was comparatively less as compared to T14 as evident from Fig. 3. In the control samples, which were grown in MM without cyfluthrin $\left(0 \mathrm{mg} \mathrm{l}^{-1}\right)$, both T14 and T25 showed only limited growth (Fig. 3). T14 and T25 exhibited higher growth at all the tested concentrations of pesticide viz., 10, 20, 50, $100 \mathrm{mg}$ $\mathrm{I}^{-1}$ with T14 exhibiting comparatively higher growth than T25 at all tested concentrations. Though growth of T14 and T25 were observed in MM even in the absence of cyfluthrin, growth increased by 46 and 33\% respectively when cyfluthrin was added. Also the difference in growth of both T14 and T25 in the presence and absence of cyfluthrin was found to be statistically significant $(\mathrm{p}<0.05)$. This implies the significant role that cyfluthrin plays as the sole carbon source in an otherwise carbon deficit medium (Chen et al., 2013). Therefore, for further quantification of cyfluthrin degradation, tests were performed using T14 strain with $100 \mathrm{mg} \mathrm{l}^{-1}$ initial cyfluthrin concentration.

After deciding on the strain to be tested (T14) and the concentration to be selected $\left(100 \mathrm{mg} \mathrm{l}^{-1}\right)$, temperature and $\mathrm{pH}$ conditions for cyfluthrin degradation were optimised. Park et al. (2006) reported the optimum $\mathrm{pH}$ of P. ganghwense strain $\mathrm{FR} 1311^{\mathrm{T}}$ as $35^{\circ} \mathrm{C}$ and $\mathrm{pH}$ 8-9. Growth of $P$. ganghwense $\mathrm{T} 14$ varied at different temperatures with highest $(\mathrm{p}<0.05)$ growth recorded in cyfluthrin medium when incubated at $30^{\circ} \mathrm{C}$ (Fig. 4) which was found to be same as the optimum temperature for the strain in normal growth medium in the absence of cyfluthrin. Temperature plays a crucial role in controlling pyrethroid

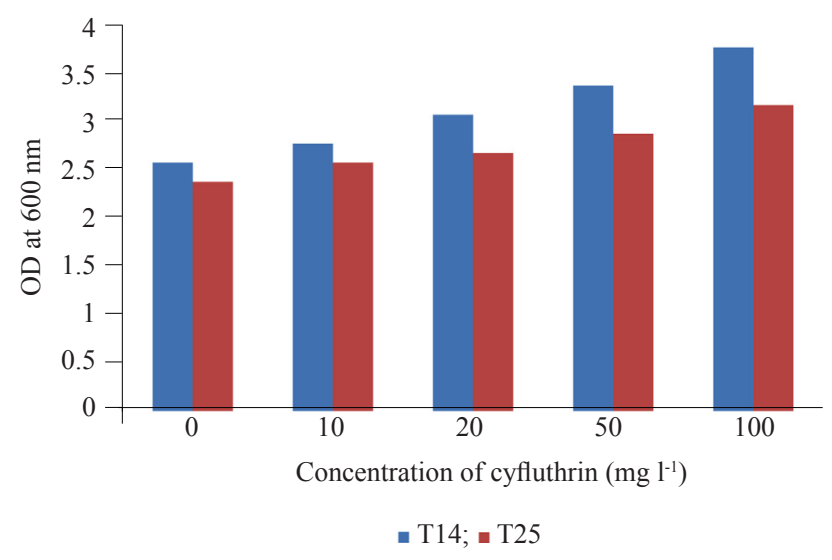

Fig. 3. Growth of $P$. ganghwense $\mathrm{T} 14$ and $\mathrm{T} 25$ strains in terms of $\mathrm{OD}_{600}$ measured after $48 \mathrm{~h}$ of incubation, at varying cyfluthrin concentrations $\left(\mathrm{mg} \mathrm{l}^{-1}\right)$ degradation. Studies by Lin et al. (2011) proved that in the biodegradation process, the pesticide degradation rate is consistent with the growth of the strain (Zhang et al., 2016). For the degradation to be maximum, growth should be at the highest levels, for which the growth conditions need to be optimum. Streptomyces sp. strain HU-S-01 exhibited a degradation rate of about $90 \%$ when grown at its optimum temperature range of $26-28^{\circ} \mathrm{C}$, whereas above $34^{\circ} \mathrm{C}$, the degradation showed a drastic dip to $10 \%$ (Lin et al., 2011). Similar was the case of Catellibacterium sp. CC-5 (Zhao et al., 2013), with highest degradation rate observed at the greatest growth of the strain. Temperature dependent degradation studies conducted by Zhang et al. (2016) showed that both high and low temperatures are detrimental to pyrethroid degradation process.

$\mathrm{pH}$ is another primary factor determining the rate of pyrethroid biodegradation (Chen et al., 2012). On optimising the $\mathrm{pH}$ conditions of $\mathrm{T} 14, \mathrm{pH}$ of 8 was found to be most favourable for bacterial growth in cyfluthrin medium (Fig. 5). The highest degradation rate at $\mathrm{pH}$ 8 could be attributed to the optimum growth of T14 at this $\mathrm{pH}$, as the growth and degradation rate are found to be concomitant factors (Zhao et al., 2013). However, growth was observed at all $\mathrm{pH}$ levels tested from 6 to 9, with $\mathrm{pH} 7$ and 8 appearing slightly closer in cell densities with highest $(\mathrm{p}<0.05)$ being at $\mathrm{pH} 8$. The type strain of $P$. ganghwense FR $1311^{\mathrm{T}}$ grows well at $\mathrm{pH}$ range of 5-11 with optimum at $\mathrm{pH} 8-9$. T14 strain also showed $\mathrm{pH}$ tolerance almost in the same range. Outside this $\mathrm{pH}$ tolerance range, the strain would become inactive leading to poor degradation (Zhao et al., 2013). Biodegradation studies in liquid media usually favour neutral conditions (Chen et al., 2012). However, adaptive $\mathrm{pH}$ of the test strain is a critical factor in this regard. For eg. Streptomyces HU-S-01 has an adaptive $\mathrm{pH}$ value between 6 and 9 with highest

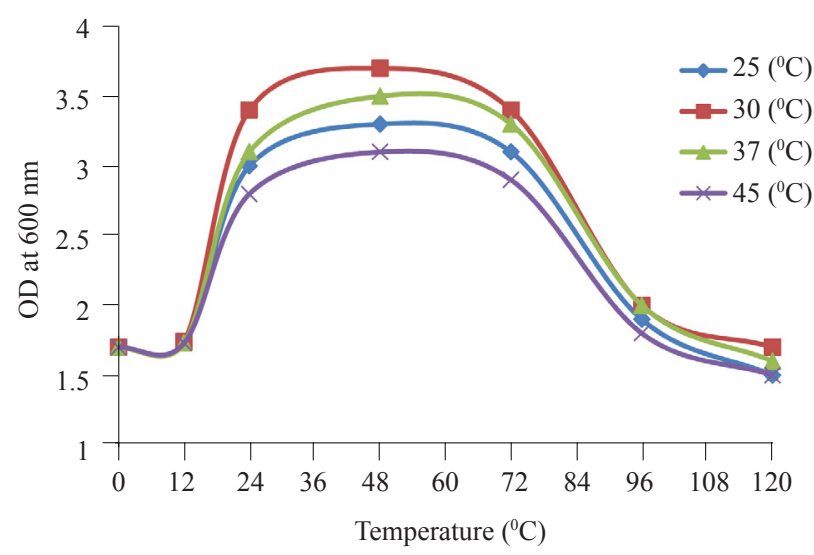

Fig. 4. Growth (in terms of $\mathrm{OD}_{600}$ measured after $48 \mathrm{~h}$ of incubation), of $P$. ganghwense T14 in mineral medium $(\mathrm{pH} \mathrm{7})$ in presence of $100 \mathrm{mg} \mathrm{l}^{-1}$ cyfluthrin at varying temperature levels 


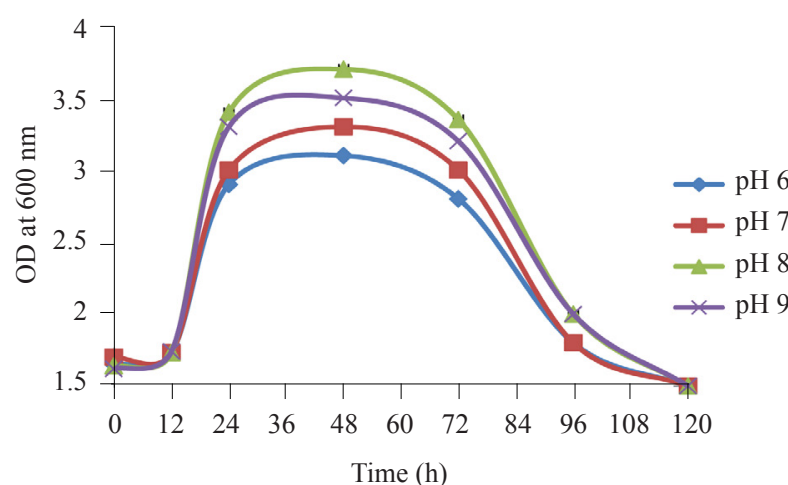

Fig. 5. Growth (in terms of $\mathrm{OD}_{600}$ measured after $48 \mathrm{~h}$ of incubation at $30^{\circ} \mathrm{C}$ ), of $P$. ganghwense $\mathrm{T} 14$ in mineral medium in presence of $100 \mathrm{mg} \mathrm{l}^{-1}$ cyfluthrin at varying $\mathrm{pH}$ levels

degradation level shown between $\mathrm{pH} 7-8$, with optimum being at $\mathrm{pH} 7.5$ (Chen et al., 2012). At pH 5.5 and 10, degradation rates were insignificant. Cypermethrin removal by Catellibacterium strain CC-5 was highest at $\mathrm{pH} 7$ followed by 8 and then 6. Below pH 6 and above $\mathrm{pH} 8$, degradation rate was not appreciable (Zhao et al., 2013). Certain strains like Ochrobactrum DG-S-01 (Chen et al., 2011b) and Stenotrophomonas strain ZS-S-01 (Chen et al., 2011c) showed pyrethroid degradation in a wide $\mathrm{pH}$ range from 5-9, with highest degradation rate showed at the highest $\mathrm{pH}$ (Chen et al., 2011b). Studies have proved that rate of pyrethroid degradation hastens at neutral and alkaline conditions whereas at acidic $\mathrm{pH}$, the process of degradation either stops or delays (Zhang et al., 2016). The low degradation rate is attributed to the increase in stability of pyrethroids at acidic $\mathrm{pH}$ making them resistant to microbial degradation (Chen et al., 2015). Furthermore, it should be noticed that at all the temperature and $\mathrm{pH}$ levels tested, growth rate was higher in cyfluthrin supplemented medium than in the control, which further substantiates the significance of cyfluthrin in bacterial growth.

In addition to $\mathrm{pH}$ and temperature, several other factors come to role when discussing the factors involved in pyrethroid biodegradation in liquid media. One important factor among these is the addition of carbon source which was reported to have both accelerating (Chen et al., 2012) as well as decelerating effects (Tiwary and Dubey, 2016) on degradation rates. For e.g. presence of glucose, beef extract and yeast extract enhanced the degradation rate of $\beta$-cypermethrin by Ochrobactrum lupini DGS-01 by approximately 8\% (Chen et al., 2011b). Also pyrethroid degrading Cladosporium sp. HU (Chen et al., 2011a), S. aureus HP-S-01 (Chen et al., 2011c) and Bacillus amyloliquefaciens AP01 (Lee et al., 2016) have shown positive response to the addition of carbon source. Here, the growth rate of the pyrethroid degrading bacteria was found to be increased by the co-metabolism with another carbon source leading to enhanced degradation rate. In contrast, biotransformation of cypermethrin by Bacillus sp. strain AKD1 and the half-life of cypermethrin, was found to be suppressed by the additional carbon source indicating the inhibitory effect of added compound on pesticide degradation (Tiwary and Dubey, 2016). This inhibition could be related to the decrease in $\mathrm{pH}$ caused by the added carbon source (Cycon et al., 2016). Pyrethroid degrading microorganisms were usually unable to initiate utilisation of pesticides as the sole carbon and energy source and therefore additional carbon sources (e.g. sucrose, glucose) were needed to start degradation (Lin et al., 2011). The ability of the strain T14 to utilise cyfluthrin as a carbon source, along with its potential to initiate proliferation without any other added carbon source indicates its excellent environmental adaptation and suitability as a bioremediant. This is indeed an important feature, of a pesticide degrading microorganism required to be employed for bioremediation in variable contaminated environments.

Fig. 6 depicts the growth curve of T14 (T) in MM supplemented with $100 \mathrm{mg} \mathrm{l}^{-1}$ cyfluthrin in comparison with control medium $(\mathrm{C} 1)$ without supplementation of cyfluthrin at the optimised temperature and $\mathrm{pH}$ conditions of $30^{\circ} \mathrm{C}$ and 8 respectively. Statistically significant differences were observed between the growth of T14 and control $(p<0.05)$. It was observed that, in test samples supplemented with cyfluthrin, after a lag phase of about $12 \mathrm{~h}$, the isolate grew rapidly for $36 \mathrm{~h}$ and reached its maximum cell density in $48 \mathrm{~h}$ and later on declined. Similarly, in the control samples also, bacterial cell density reached maximum in $48 \mathrm{~h}$ but with lower biomass as compared to test samples. As the inoculum used in the control was already in the log phase, in the control samples bacteria could easily adapt to the new environment with shorter lag phase. However for test group, a $12 \mathrm{~h}$ long lag phase was observed which could be attributed to the acclimatisation time for the bacteria to the high cyfluthrin concentration in the medium. There are reports on the use of pesticides as nutrients by microorganisms and their enzymatic conversion into non-toxic derivatives (Tang, 2018). O. lupini was reported to degrade $80 \%$ $\beta$-cypermethrin when grown in liquid media without any carbon source (Chen et al., 2011).

Size of the inoculum is another important concern in the application level. For all the experiments discussed above, the bacterial cells were inoculated at one $\mathrm{ml}$ of $10^{8}$ cells $\mathrm{ml}^{-1}$ in $50 \mathrm{ml}$ of mineral medium (MM). Studies have proved that microorganisms that are capable of degrading pyrethroids, when inoculated at levels of $10^{6}-10^{10} \mathrm{cfu} \mathrm{ml}^{-1}$, exhibit an elevated degradation rate and reduced pesticide 


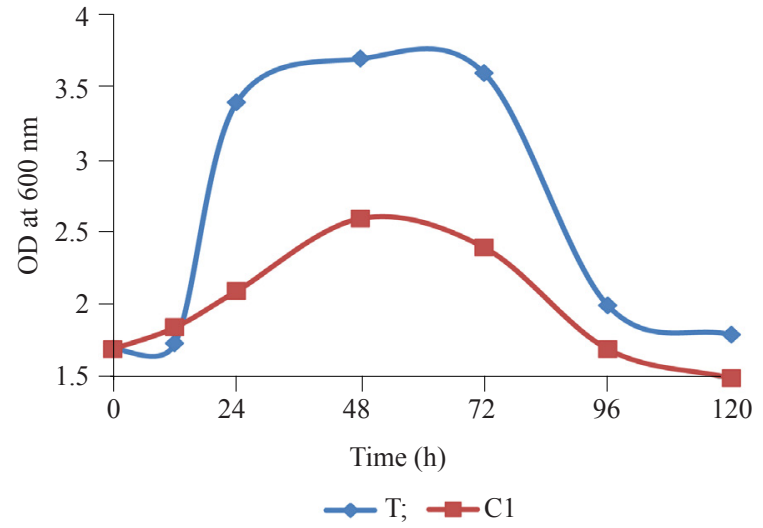

Fig. 6. Growth curve of $P$. ganghwense T14 in mineral medium supplemented with $0 \mathrm{mg} \mathrm{l}^{-1}(\mathrm{C} 1)$ and $100 \mathrm{mg} \mathrm{l}^{-1}(\mathrm{~T})$ cyfluthrin at $\mathrm{pH} 8$ and temperature $30^{\circ} \mathrm{C}$

half-life when compared to the controls (Zhang et al., 2016). At lower inoculum densities, the survival rate of the inoculum was found to be lower (Karpouzas and Walker, 2000). This initial decline in inoculum level can be overcome by a higher initial dose so that the survivors can proliferate and degrade pesticide (Karpouzas and Walker, 2000). Cycon et al. (2014) have reported that adaptation of the bacterial strain to the high pyrethroid concentration, soil conditions and use of pyrethroid as the carbon source by indigenous bacteria would lead to an initial lag phase even under high inoculum level. Also a high pyrethroid concentration was found to be an important factor influencing microbial growth (Karpouzas and Walker, 2000; Cycon et al., 2014).

Apart from the above discussed factors, another most important element for critical consideration that limits the degradation rate is the metabolic byproducts that arise from the parental compound. 3-phenoxybenzaldehyde (PBA) was found to be a common toxic byproduct in almost all Type II pyrethroid degradation process (Chen et al., 2011a; Bhatt et al., 2016). The antimicrobial property exhibited by this compound would prevent the bacterial proliferation leading to incomplete degradation (Cycon et al., 2014). However, this is found to be absent in Type I pyrethroids. In almost all Type II pyrethroids, intermediate PBA is further degraded with diaryl cleavage to form lesser toxic 1, 2-benzenedicarboxylic butyl dacyl ester (Jingjing Yang, 2018).

Chen et al. (2013) observed an elevated growth rate of Brevibacterium aureum when grown in nutrient rich cyfluthrin medium than in seawater and they opined that the medium of bacterial growth plays a key role in the pesticide degradation process. The authors attributed the exalted growth to the presence of other nutrients and thus cyfluthrin was found to have little effect on bacterial growth when grown in nutrient rich media. Nevertheless, the bacterial growth was higher in seawater with cyfluthrin than in seawater alone (Wang et al., 2019). This implies the utilisation of cyfluthrin as a growth nutrient when grown in carbon deficit medium. Therefore, in our study, the bacteria was intentionally put in a nutrient deficit medium i.e., seawater based mineral medium where they had to depend solely on cyfluthrin for the provision of carbon. When the medium is nutrient rich, cyfluthrin would have little effect on bacterial metabolism (Wang et al., 2019). Therefore in bioremediation processes, use of nutrient rich medium would prolong the remediation time as the bacteria would start utilising cyfluthrin only when the other carbon sources become scarce.

Evaluation and quantification of cyfluthrin degradation by $G C-M S / M S$ analysis

Post-120 h incubation, the treated filtrates of T along with the control filtrate $\mathrm{C} 2$ were analysed by GC-MS/MS technique to determine the cyfluthrin content. The concentrations of cyfluthrin in $\mathrm{C} 2$ filtrate was estimated as $98.2 \mathrm{mg} \mathrm{l}^{-1}$ by GC-MS/MS analysis showing $1.8 \%$ reduction as compared to the initial level of $100 \mathrm{mg} \mathrm{l}^{-1}$, which could be attributed to auto degradation of cyfluthrin. In filtrate $\mathrm{T}$, cyfluthrin concentration estimated was only $7.72 \mathrm{mg} \mathrm{l}^{-1}$. Fig. 7 shows the GC-MS/MS chromatogram of $\mathrm{T}$ filtrate post-120 $\mathrm{h}$ treatment of cyfluthrin media with T14 strain. A degradation rate of $92.13 \%$ was observed within $120 \mathrm{~h}$ (5 days) treatment using $100 \mathrm{mg} \mathrm{l}^{-1}$ cyfluthrin concentration calculated using the formula mentioned earlier with $\mathrm{C}_{\mathrm{C} 2}$ as $98.2 \mathrm{mg} \mathrm{l}^{-1}$ and $\mathrm{C}_{\mathrm{T}}$ as 7.72 $\mathrm{mg} \mathrm{l}^{-1}$, which offers an attractive potential of the strain as an effective bioremediative agent in cyfluthrin removal. The half-life of cyfluthrin was reported to be varying with environmental conditions. It has a half-life of about 193 days in water in the absence of sunlight and 12 days under exposure to sunlight. Whereas in soil without oxygen, it takes 34 days and 56 days with oxygen (Casjens, 2002). In the present study, the test was performed in liquid sample under dark condition for 5 days and the loss of cyfluthrin via auto-degradation recorded was only $1.8 \%$ which can be considered as meagre. It has been reported that the compounds released during the stationary phase also could increase the solubility of the pesticide thereby enhancing the degradation rate (Vyas and Dave, 2011). On measuring the $\mathrm{OD}_{600}, \mathrm{~T}$ and $\mathrm{C} 1$ displayed a growth pattern similar to Fig. 6. Obviously, no variation in optical density was observed in uninoculated sample $\mathrm{C} 2$.

Cyfluthrin belongs to Type II pyrethroids which have cyano group in their structure (Laskowski, 2002). Metabolomic assessment studies of cyfluthrin degradation by $P$. ganghwense strain PGS6046 elucidated the absence of cyano group in its degradation products which clearly 

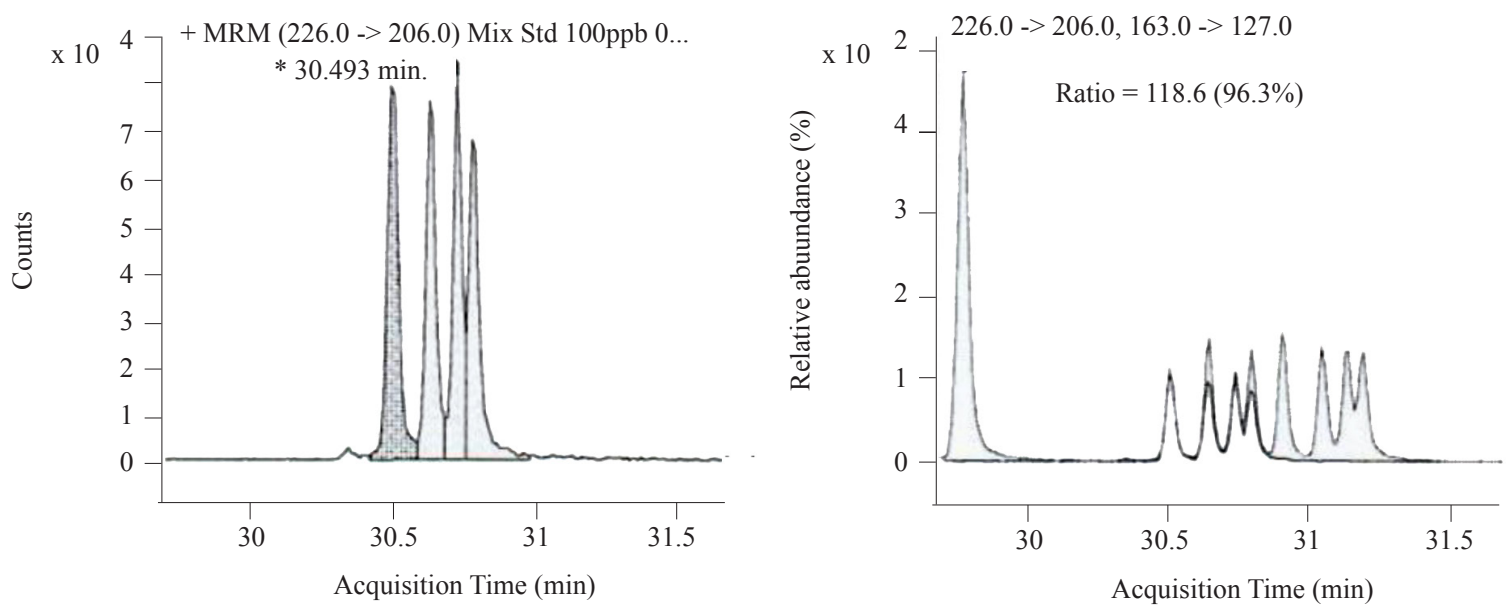

Fig. 7. Extracted ion chromatogram of $\mathrm{T}$ filtrate post-120 h treatment of cyfluthrin media with P. ganghwense T14 strain from GC-MS/MS analysis. (a) with qualifier and (b) with qualifier and quantifier

indicates the use of cyano group in cyfluthrin as the carbon source leading to its degradation (Wang et al., 2019). Thus cyfluthrin was reported to act as a carbon source to $P$. ganghwense when grown in a carbon deficit medium (Wang et al., 2019). It was also reported that the cyano group in cyfluthrin is microbiologically metabolised to form cyanoalanine (Yoshikawa et al., 2000). Therefore, the reduction in cyfluthrin content when treated with T14 could be possibly due to the utilisation of cyano group in the pesticide. The nature of the byproduct formed by this degradation and its future ecological impacts needs to be studied further. Wang et al. (2019), investigated on the metabolic profile of $P$. ganghwense strain 6046 (PGS6046) during cyfluthrin degradation and identified 156 metabolites, none of which were found to be toxic. The type of medium, concentration of cyfluthrin and time of incubation were found to have significant influence on the metabolic profile (Wang et al., 2019). Chen et al. (2013) reported B. aureum DG-12 having $87.4 \%$ cyfluthrin degradation $\left(50 \mathrm{mg} \mathrm{l}^{-1}\right)$ potential within a period of 5 days. Chen et al. (2015) demonstrated that the degradation rate is higher when the initial concentration of cyfluthrin is lower. As per the reports, degradation rate would further rise if a lower initial concentration of cyfluthrin is used (Chen et al., 2015).

Cytotoxicity evaluation of T, C1 and C2 filtrates using fish cell line EM4SpEx

Fish cell lines act as a valid and reliable means to assess pesticide cytotoxicity (Castano et al., 2003). In the initial cytotoxicity assay conducted to assess the toxicity of cyfluthrin to EM4SpEx cell line, the cells were found to respond in a dose-dependent manner to cyfluthrin exposure with maximum cell destruction observed in cell monolayers treated with cyfluthrin at $1 \mu \mathrm{g} \mathrm{ml}^{-1}$ of the active ingredient. In the subsequent assay conducted to compare cytotoxicity of filtrates from $\mathrm{T}, \mathrm{C} 1$ and $\mathrm{C} 2$ to EM4SpEx cell line, difference in morphological changes were clearly evident between control cells without exposure to any of the filtrates $(\mathrm{C} 0)$ and those exposed to $\mathrm{T}, \mathrm{C} 1$ and $\mathrm{C} 2$ filtrates (Fig. 8). In the control wells (C0) exposed to L-15 medium alone, the cell monolayer appeared homogeneous (Fig. 8a) maintaining typical fibroblast morphology after 5 days of incubation. In case of the cell monolayers exposed to filtrate from $\mathrm{C} 1$ (Fig. $8 \mathrm{~b}$ ), on $5^{\text {th }}$ day postexposure, slight damage to the cells were observed. These minor changes in cell morphology even in the absence of cyfluthrin could be attributed to the effect of extracellular products released by the bacterial cells of T14 (Olgerts et al., 1972). The extent of cell destruction was higher in cells exposed to filtrates containing cyfluthrin ( $\mathrm{T}$ and $\mathrm{C} 2$ ) with comparatively lesser cell destruction observed in T (Fig. 8c). As evident from Fig. 8d, almost complete destruction of cells and rounding occurred when treated with C2 filtrate which had only cyfluthrin and MM. Cytotoxic effects on cells in $\mathrm{T}$ were found to be appreciably low in all the triplicate wells as compared to $\mathrm{C} 2$, which clearly indicated biodegradation of cyfluthrin by the bacterial strain P. ganghwense T14. The results clearly indicate that the probable biodegraded metabolites of cyfluthrin meditated by $P$. ganghwense T14, in T filtrate are less toxic in nature than the parent compound.

As evidenced from Fig. 8c and d, toxicity of $\mathrm{T}$ was found to be comparatively lesser than $\mathrm{C} 2$ which implies the lesser toxicity of degradation products than the parent cyfluthrin. On a comparative analysis, the effect of cyfluthrin on fish cell line was found to have reduced when treated with T14. Here fish cell line is used as a 


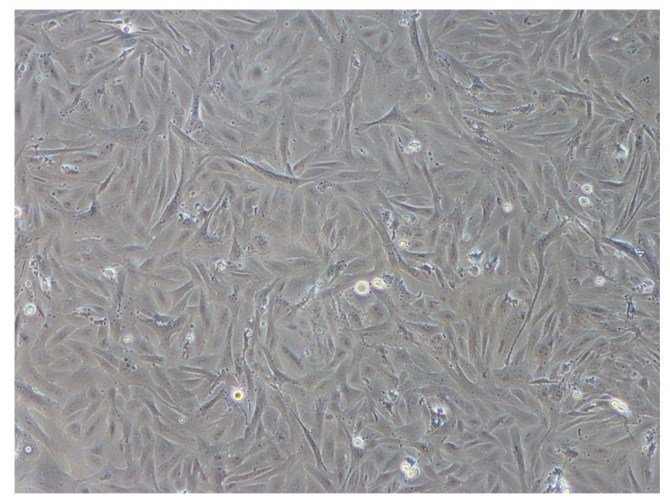

(a)

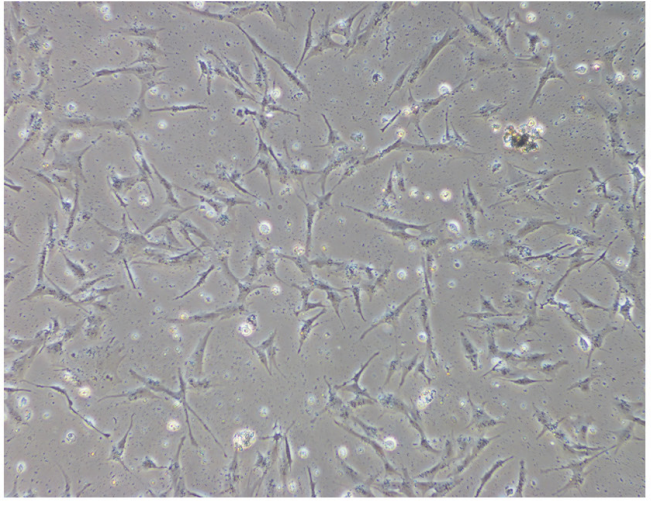

(c)

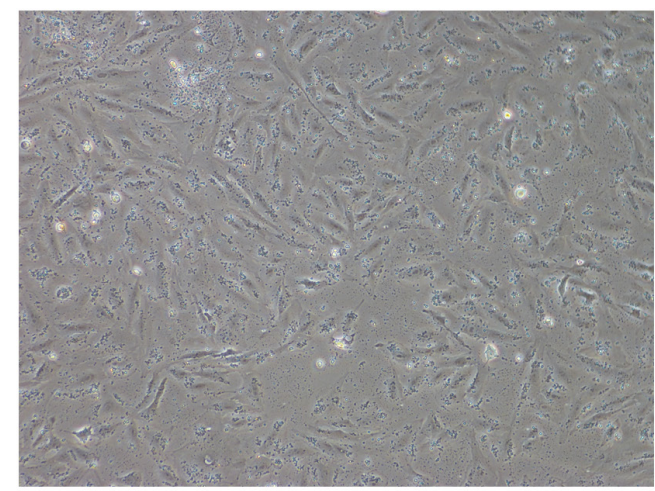

(b)

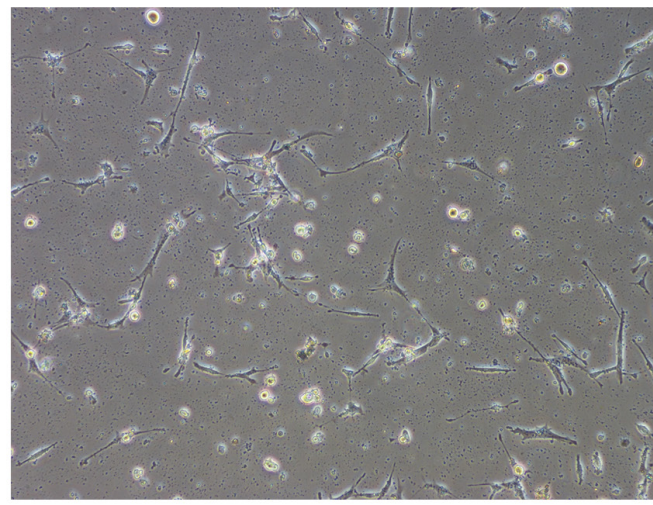

(d)

Fig. 8. Phase contrast photomicrograph of fish cell line EM4SpEx on day 5 incubation after exposure to filtrates. (a) Control cells (C0) showing fully confluent monolayer comprising normal cells; (b) Cells exposed to filtrate $\mathrm{C} 1$ showing slight disruption of the monolayer and presence of granules in the medium; (c) Cells exposed to filtrate T displaying shrinking of cells and a discernible reduction in the density of the monolayer and (d) Cells exposed to filtrate $\mathrm{C} 2$, exhibiting rounding and considerable detachment of cells with majority of the cells found dead

tool to qualitatively analyse the difference in cyfluthrin cytotoxicity post-bacterial treatment. Fish cell lines have been successfully employed as a biological alternative to the use of live animals for ecotoxicology studies, especially to monitor potential toxic effects of contaminants in aquatic ecosystems (Davoren et al., 2005). Damages to fishes by pyrethroids in aquatic ecosystems should not be disregarded. Run off of pyrethroids from the agricultural and urban areas into the waterways have become a serious concern. Marine fishes are severely affected by these chemicals and their concentrations have now reached a level which is lethally and sublethally toxic to aquatic organisms (Antwi and Reddy, 2015). Studies on toxic effect of organochlorine and organophosphorus pesticide residues on tilapia fish tissue revealed that continuous exposure to pesticide residues would result in significant haemato-biochemical alterations and DNA damage in vital organs like gills and liver (Elbialy et al., 2015). Endocrine disrupting potential of pyrethroids in mammals and fishes adds up the criticality of the situation (Susanne et al., 2016).
The bacterial strain $P$. ganghwense T14 isolated and characterised in this study, clearly demonstrated its ability to utilise cyfluthrin as carbon source and is effective in degrading the pesticide at a concentration as high as $100 \mathrm{mg} \mathrm{l}^{-1}$. Further investigations on metabolomics are necessary to provide insights into the microbial processes involved in the pesticide degradation and transformation. Also, the scope extends further to the use of genetic engineering tools to modify the enzyme producing bacterial genes as well as recombinant DNA technology, to engineer bacteria having higher pyrethroid degradation potential. Exploitation of hydrolysing enzymes responsible for the degradative ability in bacterial strains can also be a promising strategy. The pyrethroid degrading organisms are reported to target the ester bond in the pesticide and hydrolyse it by carboxyl esterases (carboxylic-ester hydrolase, EC 3.1.1.1), yielding carboxylate and alcohol (Aranda et al., 2014). Because of the broad spectrum activity of these enzymes, esterases can degrade various pyrethroids with similar molecular structure (Wu et al., 
2006). However, the rate of hydrolysis may vary. This points towards the possibility for the co-application of other pesticide degrading strains along with $P$. ganghwense T14 for a complete remedial strategy. In addition, microbes having potential to degrade a wide range of pyrethroids can be efficiently utilised as a consortium to overcome the problem of formation and accumulation of toxic metabolites during pesticide degradation. This can be made possible by making use of the varying ability of the members of the consortium to use the intermediate toxic products as their growth substrates. This paper offers a scope on study of co-metabolism of other pyrethroid degrading bacteria with $P$. ganghwense T14 strain. Several bacterial strains belonging to the genera Bacillus, Brevibacillus, Ochrobactrum, Pseudomonas, Serratia and Sphingobium were found to be highly effective in pyrethroid degradation. Bacillus strains were reported to completely degrade cypermethrin and bifenthrin at 100-1200 $\mathrm{mg} \mathrm{l}^{-1}$ concentrations in less than 7 days (Tiwary and Dubey, 2016). Similarly, Ochrobactrum sp. and Serratia nematodiphila were found to be capable of directly utilising more than $90 \%$ of the initial dose of cypermethrin (100 $\left.\mathrm{mg}^{-1}\right)$ within 5-10 days. Among fungi, removal of fenvalerate $\left(50-400 \mathrm{mg} \mathrm{l}^{-1}\right)$ by Cladosporium sp. and bifenthrin (100-400 $\left.\mathrm{mg} \mathrm{l}^{-1}\right)$ by Candida pelliculosa were reported (Chen et al., 2011a). Some bacterial strains have been reported to degrade a wide spectrum of pyrethroids (Guo et al., 2009). Many studies have reported an efficient elimination of pesticides by microbial treatment by simultaneous biostimulation and bioaugmentation (Guo et al., 2014) which was explained as due to the increase in the catabolic potential of the soil and by the synergistic ability of the native microorganisms to degrade certain pesticides (Zhang et al., 2016). Among the various approaches tried, biological methods were found to be more effective, economic and ecofriendly (Akbar et al., 2015). Studies have proved the ability of diverse microorganisms in successfully eliminating pyrethroids from water and soils (Jin and Webster, 1998). When it comes to the field level application for bioremediation, environmental elements comes into role. Since the abiotic factors such as temperature, $\mathrm{pH}$, nutrient level, inoculum size, moisture, organic matter content, the initial pesticide concentration and additional carbon sources (Zhang et al., 2010) critically control the onsite degradation efficacy, an elaborate study on the interactions of these microorganisms with the environment is essential, prior to exploration of its field application. The most important among the biotic factors are interaction between autochthonous and inoculated microorganisms including predation, competition for space and food. The survival rate of inoculants in the treatment area is another important factor that determines the success rate of bioremediation (Karpouzas and Walker, 2000). Loss of degradative ability of the inoculum in situ or antagonistic inhibition by indigenous microorganisms is detrimental factors in degradation process (Cycon et al., 2014). However, repeated inoculation with concomitant progress in degradation as well as use of immobilised microorganisms are possible alternative counteracts. Immobilisation not just extends the abidance and vitality of inoculants but also protect the organism against adverse conditions (Tallur et al., 2015).

The detrimental effects of the pesticide use and its effects on the environment have been well studied. Although, pyrethroids have comparatively lesser toxicity towards non-target organisms, its long-term exposure may impair organ functions (Soni et al., 2011) and can be carcinogenic as well as anti-androgenic (Zhang et al., 2010). Reports have shown persistence of cyfluthrin in crops above its Maximum Residue Limit (CAC, 2004). Therefore the remediation of pesticide contaminated sites and prevention of further accumulation is an urgent concern. The confirmed negative effect of pyrethroids on the ecosystem emphasises the need of a safe, efficient and economical strategy for pesticide removal from the contaminated environments. This paper offers a small contribution to the big scenario of bacterial mediated bioremediative strategies.

\section{Acknowledgments}

We thank the Director, ICAR-CMFRI, Kochi for all the research facilities provided. The first author expresses gratitude to Cochin University of Science and Technology, Kochi for granting Ph. D admission and to DST, New Delhi for providing financial assistance.

\section{References}

AFNOR 2009. Foods of plant origin - Determination of pesticide residues using GC-MS and/or LC-MS/MS following acetonitrile extraction/partitioning and clean-up by dispersive SPE-QuEChERS-method. vol V03-061; NF EN 15662:2009-01-01. FrenchAssociation for Standardisation, France.

Agler, M. T., Ruhe, J., Kroll, S., Morhenn, C., Kim, S. T., Weigel, D. and Kemen, E. M. 2016. Microbial hub taxa link host and abiotic factors to plant microbiome variation. PLoS Biol., 14(1): e1002352. https://doi.org/10.1371/ journal.pbio.1002352.

Akbar, S., Sultan, S. and Kertesz, M. 2015. Determination of cypermethrin degradation potential of soil bacteria along with plant growth-promoting characteristics. Curr. Microbiol., 70: 75-84. doi:10.1007/s00284-014-0684-7.

Almakkawy, H. K. and Madbouly, M. D. 1999. Persistence and accumulation of some organic insecticides in Nile water and fish. Resour. Conserv. Recycl., 27(1-2): 105-115. 
Anastassiades, M., Lehotay, S. J., Stajnbaher, D. and Schenck, F. J. 2003. Fast and easy multiresidue method employing acetonitrile extraction/partitioning and "dispersive solid-phase extraction" for the determination of pesticide residues in produce. J. AOAC Int., 86: 412-431. DOI: $10.1093 /$ jaoac/86. 2.412 .

Antwi, F. B. and Reddy, G. V. P. 2015. Toxicological effects of pyrethroids on non-target aquatic insects. Environ. Toxicol. Pharmacol., 40: 915-923. doi: 10.1016/j.etap.2015.09.023.

Anzai, Y., Kim, H., Park, J. Y., Wakabayashi, H. and Oyaizu, H. 2000. Phylogenetic affiliation of the Pseudomonads based on 16S rRNA sequence. Int. J. Syst. Evol. Microbiol., 50: 1563-1589. doi: 10.1099/00207713-50-4-1563.

AOAC 2007. Pesticide residues in foods by acetonitrile extraction and partitioning with magnesium sulfate gas chromatography/mass spectrometry and liquid chromatography/tandem mass spectrometry First Action 2007. Official methods of analysis 2007.01, Association of Official Analytical Chemists, Rockville, Maryland, USA.

Aranda, J., Cerqueira, N. M. F. S. A., Fernandes, P. A., Roca, M., Tuñon, I. and Ramos, M. J. 2014. The catalytic mechanism of carboxyl esterases: A computational study. Biochemistry, 53: 5820-5829. doi: 10.1021/bi5 00934j.

Baumann, P. and Baumann, L. 1984. Genus II. Photobacterium Beijerinck 1889. In: Kreig, N. R. (Ed.), Bergey's manual of systematic bacteriology, vol. 1, The Williams and Wilkins Co., Baltimore, USA, p. 539-545.

Bhatt, P., Sharma, A., Gangola, S., Khati, P., Kumar, G. and Srivastava, A. 2016. Novel pathway of cypermethrin biodegradation in a Bacillus sp. strain SG2 isolated from cypermethrin contaminated agriculture field. Biotechnology, 6: 45. doi: 10.1007/s13205-016-0372-3.

CAC 2004. Maximum residue limits in foods and feeds. Joint FAO and WHO Food Standards Programme, Codex Alimentarius Commission, $36^{\text {th }}$ session, CX/PR 04/5.157, Part A1, New Delhi, India.

Casjens, H. 2002. Environmental fate of cyfluthrin. Environmental Monitoring Branch, Department of Pesticide Regulation, California Environmental Protection Agency, California, USA.

Castano, A., Bols, N., Braunbeck, T., Dierickx, P., Halder, M., Isomaa, B. and Segner, H. 2003. The use of fish cells in ecotoxicology: The report and recommendations of ECVAM Workshop 47, ALTA Altern. Lab. Anim., 31(3): 317-351. https://doi.org/10.1177/026119290303100314.

Chen, S., Hu, Q., Hu, M., Luo, J., Weng, Q. and Lai, K. 2011a. Isolation and characterisation of a fungus able to degrade pyrethroids and 3- phenoxybenzaldehyde. Bioresour. Technol., 102: 8110-8116. doi: 10.1016/j. biortech.2011.06.055.

Chen, S., Hu, M., Liu, J., Zhong, G., Yang, L. and Rizwan-ulHaq, M. 2011b. Biodegradation of beta-cypermethrin and 3-phenoxybenzoic acid by a novel Ochrobactrum lupini
DG-S-01. J. Hazard. Mater., 187: 433-440. doi: 10.1016/j. jhazmat.2011.01.049.

Chen, S., Lai, K., Li, Y., Hu, M., Zhang, Y. and Zeng, Y. 2011c. Biodegradation of deltamethrin and its hydrolysis product 3-phenoxybenzaldehyde by a newly isolated Streptomyces aureus strain HP-S-01. Appl. Microbiol. Biotechnol., 9: 1471-1483. doi: 10.1007/s00253-011-3136-3.

Chen, S., Geng, P., Xiao, Y. and Hu, M. 2012. Bioremediation of $\beta$ cypermethrin and 3-phenoxybenzaldehyde contaminated soils using Streptomyces aureus HP-S-01. Appl. Microbiol. Biotechnol., 94: 505-515. doi: 10.1007/s00253-011-3640-5.

Chen, S., Dong, Y. H., Chang, C., Deng, Y., Zhang, X. F. and Zhong, G. 2013.Characterisation of a novel cyfluthrindegrading bacterial strain Brevibacterium aureum and its biochemical degradation pathway. Bioresour. Technol., 132: 16-23. doi: 10.1016/j.biortech.2013.01.002.

Chen, S., Deng, Y., Chang, C., Lee, J., Cheng, Y. and Cui, Z. 2015. Pathway and kinetics of cyhalothrin biodegradation by Bacillus thuringiensis strain ZS-19. Sci. Rep., 5: 87-84. doi: $10.1038 /$ srep08784.

Connell, D. W. and Hawker, D. W. 1991. Pollution in tropical aquatic systems. CRC Press, Boca Raton, Florida, USA, $252 \mathrm{pp}$.

Cyco'n, M., Zmijowska, A. and Piotrowska-Seget, Z. 2014. Enhancement of deltamethrin degradation by soil bioaugmentation with two different strains of Serratia marcescens. Int. J. Environ. Sci. Technol., 11: 1305-1316. doi: 10.1007/s13762-013-0322-0.

Davoren, M., Nishuilleabhain, S., Hartl, M. G. J., Sheehan, D., O'Brien, N. M., O'Halloran, J., Van Pelt, F. N. A. M. and Mothersill, C. 2005. Assessing the potential of fish cell lines as tools for the cytotoxicity testing of estuarine sediment aqueous elutriates. Toxicol. In Vitro, 19: 421-431. doi:10.1016/j.tiv.2004.12.002.

DeLorenzo, M. E., Scott, G. I. and Ross, P. E. 2001. Toxicity of pesticides to aquatic microorganisms: A review. Environ. Toxicol. Chem., 20: 84-98. doi: 10.1897/1551-5028(2001) $020<0084$ :toptam $>2.0$. co; 2 .

Elbialy, Z. I., Ismail, T., Abdelhady, D. H. and Elasely, A. M. 2015. Assessment of genotoxic effects of pesticide residues and related haemato-biochemical parameters on farmed Nile tilapia Oreochromis niloticus L. in Kafrelsheikh Governorate, Alexandria. J. Vet. Sci., 44: 136-146. https:// doi.org/10.5455/ajvs.176708.

Esther, C. P., Nancy, J. G., Julie, C. F., Robert, H. R. and Elizabeth, A. 1997. Ecotoxicology of tropical marine ecosystems. Environ. Toxicol. Chem., 16(1): 12-40. https:// doi.org/10.1002/etc.5620160103.

Ferguson, W. E. G. and Johannes, R. E. 1975. Tropical marine pollution, $12^{\text {th }}$ edn. Elsevier, New York, USA, p.175-178.

Glynn, P. W., Rumbold, D. G. and Snedaker, S. C. 1995. Organochlorine pesticide residues in marine sediment and biota from the northern Florida reef tract. Mar. Pollut. Bull., 30: 397-402. https://doi.org/10.1016/0025-326X(94) 00206-O. 
Glynn, P. W., Szmant, A. M., Corcoran, E. F. and Shabica, S. V. C. 1989. Condition of coral reef cnidarians from the northern Florida reef tract: Pesticides, heavy metals and histopathological examination. Mar. Pollut. Bull., 20: 568-576. https://doi.org/10.1016/0025-326X(89)90359-7.

Grant, R, J., Daniell, T. J. and Betts, W. B. 2002. Isolation and identification of synthetic pyrethroid-degrading bacteria. J. Appl. Microbiol., 92: 534-540. doi: 10.1046/j.13652672. 2002.01558.x

Guo, Q., Zhang, J., Wan, R. and Xie, S. 2014. Impacts of carbon sources on simazine biodegradation by Arthrobacter strain SD3-25 in liquid culture and soil microcosm. Int. Biodeter. Biodegr., 89: 1-6. doi: 10.1016/j.ibiod.2013.12.018.

Guo, P., Wang, B., Hang, B., Li, L., Ali, S. W. and He, J. 2009. Pyrethroid-degrading Sphingobium sp. JZ-2 and the purification and characterisation of a novel pyrethroid hydrolase. Int. Biodeter. Biodegr., 63: 1107-1112. doi:10.1016/j.ibiod.2009.09.008.

Hall, T. A. 1999. BioEdit: A user-friendly biological sequence alignment editor and analysis program for Windows 95/98/NT. Nucleic Acids Symp. Ser., 41: 95-98.

Hartsell, S. E. 1953. The preservation of bacterial cultures under paraffin oil. Appl. Microbiol., 1(1): 36-41.

Jingjing, Y., Yanmei, F., Hui, Z., Jie, L., Fang, Y., Lianhui, Z. and Shaohua, C. 2018. Characterisation of a pyrethroiddegrading Pseudomonas fulva strain P31 and biochemical degradation pathway of D- Phenothrin. Front. Microbiol., 9. https://doi.org/10.3389/fmicb.2018.01003.

Jin, H. and Webster, G. R. B. 1998. Dissipation of cypermethrin and its major metabolites in litter and elm forest soil. J. Environ. Sci. Health B., 33: 319-345. doi:10.1080/03601239809373149.

Johannes, R. E. and Betzer, S. B. 1975. Introduction: Marine communities respond differently to pollution in the tropics than at higher latitudes. In: Ferguson Wood, E. J. and Johannes, R. E. (Eds.), Tropical marine pollution, Elsevier, New York, USA, p. 1-12.

Karlsen, C., Ellingsen, A. B., Wiik Nielsen, C., Winther Larsen, H. C., Colquhoun, D. and Sorum, H. 2014. Host specificity and clade dependent distribution of putative virulence genes in Moritella viscosa. Microb. Pathog., 77:53-55. https://doi.org/10.1016/j.micpath. 2014.09.014.

Karpouzas, D. G. and Walker, A. 2000. Factors influencing the ability of Pseudomonas putida to degrade ethoprophos in soil. Soil Biol. Biochem., 32: 1753-1762. doi: 10.1016/ S0038-0717(00)00093-6.

Laskowski, D. A. 2002. Physical and chemical properties of pyrethroids. Rev. Environ. Contam. Toxicol.,174: 49-170. doi:10.1007/978-1-4757-4260-2_3.

Lee, Y. S., Lee, J. H., Hwang, E. J., Lee, H. J., Kim, J. H. and Heo, J. B. 2016. Characterisation of biological degradation cypermethrin by Bacillus amyloliquefaciens AP01. J. Appl. Biol. Chem., 59: 9-12. doi: 10.3839/jabc.2016.003.
Lewis, S. E., Brodie, J. E. and Bainbridge, Z. T. 2009. Herbicides: A new threat to the Great Barrier Reef. Environ. Pollut., 157(8-9): 2470-2484.

Lin, Q. S., Chen, S. H., Hu, M. Y., Rizwan-ul-Haq, M., Yang, L. and $\mathrm{Li}, \mathrm{H}$. 2011. Biodegradation of cypermethrin by a newly isolated actinomycetes HU-S-01from wastewater sludge. Int. J. Environ. Sci. Technol., 8: 45-56.

McCloskey, L. R. and Chesher, R. H. 1971. Effects of manmade pollution on the dynamics of coral reefs. U. S. Department of the Interior, Washington DC, USA, p. 229-257.

Olafson, R.W. 1978. Effect of agricultural activity on levels of organochlorine pesticides in hard corals, fish and molluscs from the Great Barrier Reef. Mar. Environ. Res., 1: 87-107.

Olgerts, R., Pavlovskis, P. and Francis B. Gordon 1972. Pseudomonas aeruginosa exotoxin: Effect on cell cultures. J. Infect. Dis., 125(6): 631-636. https://doi.org/10. 1093/infdis/125.6.631.

Park, Y. D., Baik, K. S., Chi Seong and Bae, K. S. 2006. Photobacterium ganghwense sp. nov., a halophilic bacterium isolated from seawater. J. Syst. Evol. Microbiol., 56: 745-749. doi: 10.1099/ijs.0.63811-0.

Sambrook, J. and Russell, D. W. 2006. Purification of nucleic acids by extraction with phenol:chloroform. CSH Protoc., doi: $10.1101 / \mathrm{pdb}$.prot445510.1101/pdb.prot4455.

Scott, P. J. B. 1990. Chronic pollution recorded in coral skeletons in Hong Kong. J. Exp. Mar. Biol. Ecol., 139: 51-64. https:// doi.org/10.1016/0022-0981(90)90038-E.

Soni, I., Syed, F., Bhatnagar, P. and Mathur, R. 2011. Perinatal toxicity of cyfluthrin in mice: Developmental and behavioral effects. Hum. Exp. Toxicol., 30: 1096-1105. doi:10.1177/0960327110391386.

Stebbing, A. R. D. and Brown, B. E. 1984. Marine ecotoxicological tests with coelenterates. Ecotoxicological testing for the marine environment, vol. 1. State University of Ghent and Institute of Marine Scientific Research, Bredene, Belgium, p. 307-339.

Susanne, M. B., Molly, K. G., Nicholas, L. F., Richard, E. C. and Daniel, S. 2016. Pyrethroid pesticides as endocrine disruptors: Molecular mechanisms in vertebrates with a focus on fishes. Environ. Sci. Technol., 50(17): 8977-8992. doi: 10.1021/acs.est.6b02253.

Tallur, P. N., Mulla, S. I., Megadi, V. B., Talwar, M. P. and Ninnekar, H. Z. 2015. Biodegradation of cypermethrin by immobilised cells of Micrococcus sp. strain CPN 1. Braz. J. Microbiol., 46: 667-672. doi: 10.1590/ S1517838246320130557.

Tamura, K., Peterson, D., Peterson, N., Stecher, G., Nei, M. and Kumar, S. 2011. MEGA5: Molecular Evolutionary Genetics Analysis using Maximum Likelihood, Evolutionary Distance and Maximum Parsimony methods. Mol. Biol. Evol., 28(10): 2731-2739. https://doi.org/10.1093/molbev/ msr121. 
Tang, W. 2018. Research progress of microbial degradation of organophosphorus pesticides. Prog. Appl. Microbiol., 1: 29-35.

Tiwary, M. and Dubey, A. K. 2016. Cypermethrin bioremediation in presence of heavy metals by a novel heavy metal tolerant strain, Bacillus sp. AKD1. Int. Biodeter. Biodegr., 108: 42-47. doi:10.1016/j.ibiod. 2015.11.025.

Vyas, T. K. and Dave, B. P. 2011. Production of biosurfactant by Nocardia otitidiscaviarum and its role in biodegradation of crude oil. Int. J. Environ. Sci. Technol., 8: 425-435. https:// doi.org/10.1007/BF 03326229.

Wang, T., Hu, C. and Zhang, R. 2019. Mechanism study of cyfluthrin biodegradation by Photobacterium ganghwense with comparative metabolomics. Appl. Microbiol. Biotechnol., 103: 473-488. https://doi.org/10. 1007/s00253-018-9458-7.

Wijsman, B. M. 1974. Habitat-induced modification of reef corals (Faviidae) and its consequences for taxonomy. Proceedings of the $2^{\text {nd }}$ International Symposium on Coral Reefs, 2: 217-228. The Great Barrier Reef Committee, Brisbane, Australia.

Wu, P. C., Liu, Y. H., Wang, Z. Y., Zhang, X. Y., Li, H. and Liang, W. Q. 2006. Molecular cloning, purification and biochemical characterisation of a novel pyrethroidhydrolyzing esterase from Klebsiella sp. strain ZD112. J. Agric. Food Chem., 54: 836-842. doi: 10.1021/ jf052691u.

Yoshikawa, K., Kyoko, A. and Miyuki, N. 2000. Betacyanoalanine production by marine bacteria on cyanidefree medium and its specific inhibitory activity towards cyanobacteria. Appl. Environ. Microbiol., 66(2): 718-722. doi:10.1128/aem.66.2.718-722.2000

Zhang, C., Jia, L., Wang, S., Qu, J., Li, K. and Xu, L. 2010 Biodegradation of beta-cypermethrin by two Serratia spp. with different cell surface hydrophobicity. Bioresour. Technol., 101: 3423-3429. doi: 10.1016/j. biortech.2009.12.083.

Zhang, H., Zhang, Y., Hou, Z., Wang, X., Wang, J. and Lu, Z. 2016. Biodegradation potential of deltamethrin by the Bacillus cereus strain Y1 in both culture and contaminated soil. Int. Biodeter. Biodegr., 106: 53-59. doi:10.1016/j. ibiod 2015.10.005.

Zhao, H., Geng, Y., Chen, L., Tao, K. and Hou, T. 2013. Biodegradation of cypermethrin by a novel Catellibacterium sp. strain CC-5 isolated from contaminated soil. Can. J. Microbiol., 59: 311-317. doi: 10.1139/cjm2012-0580. 